Crop Breeding and Applied Biotechnology 16: 42-47, 2016

Brazilian Society of Plant Breeding. Printed in Brazil

\title{
ARTICLE
}

http://dx.doi.org/10.1590/1984-70332016v16n1a7

\section{Coffea arabica clones resistant to coffee leaf miner}

Alex Paulo Mendonça ${ }^{1}$, Juliana Vieira Almeida Nonato ${ }^{1}$, Vinícius Teixeira Andrade ${ }^{1}$, Bárbhara Joana dos Reis Fatobene ${ }^{1}$, Masako Toma Braghini ${ }^{1}$, Angelica Prela-Pantano ${ }^{1}$ and Oliveiro Guerreiro Filho ${ }^{1 *}$

Received 10 February 2015

Accepted 03 October 2015

\begin{abstract}
Brazilian arabica coffee production is based on a set of highly productive cultivars sexually propagated. All of them are susceptible to coffee leaf miner, Leucoptera coffeella, and most of them are also susceptible to coffee leaf rust, Hemileia vastatrix. Aiming to reduce the selection process of cultivars with multiple resistances to both biotic constraints, the Coffea arabica clones 760 , 1059, 1064 and 1215 were evaluated under field conditions. The mean yield of four C. arabica clones was not statistically different from the experimental controls; however, the yield of clone 1059 was 21\% higher than the control cultivar Obatã IAC 1669-20. Leaf miner resistance level in all the evaluated clones remained the same as the mother plant's. However, the same did not occur for resistance to $H$. vastatrix, due to the emergence of new pathogen races. In summary, it is potentially feasible the adoption of clone 1059 as a new clonal cultivar resistant to coffee leaf miner.
\end{abstract}

Key words: Coffee breeding, Hemileia vastatrix, Leucoptera coffeella, plant insect resistance.

\section{INTRODUCTION}

The competitiveness of Brazilian coffee production is due mainly to the availability of cultivars adapted to various production areas. This set of Coffea arabica cultivars were obtained by pedigree selection, occasionally associated with backcrossing methods (Medina-Filho et al. 2007), and were propagated through seeds. Except for a group of cultivars resistant to coffee leaf rust, Hemileia vastatrix Berkeley and Broome (Carvalho et al. 2008, Fazuoli et al. 2008), most cultivars are susceptible to other biotic agents, such as coffee leaf miner Leucoptera coffeella Guérin-Méneville. Coffee leaf miner, the major coffee pest, is responsible for significant losses, reducing crop efficiency, especially in some areas in southeastern Brazil (Souza et al. 1998).

Resistant coffee plants have been obtained through the transfer of resistance genes from $C$. racemosa to the susceptible C. arabica cultivars (Guerreiro-Filho 2006). However, homogeneous and stable populations, sexually propagated, have not been obtained yet, suggesting that resistance inheritance is more complex than the control by two dominant and complementary genes (Guerreiro-Filho et al. 1999).
Thus, the cloning of resistant coffee plants with desirable agronomic traits may represent a viable alternative to be explored by different methods of vegetative propagation, such as the cutting of orthotropic branches, or the somatic embryogenesis through in vitro culture of leaf tissue (Bertrand et al. 2011).

The present study evaluated the agronomic performance of $C$. arabica clones derived from high-yield mother plants resistant to L. coffeella, under field conditions, in Campinas, Brazil.

\section{MATERIAL AND METHODS}

The progeny trial 540 (PT 540), including six treatments, was established in April 2007, in the Experimental Center of Instituto Agronômico (IAC), in Campinas (lat 22 $2^{\circ}$ ' ' S, long $47^{\circ} 03^{\prime} \mathrm{W}$, alt $854 \mathrm{~m}$ asl), Brazil. Clones of four mother plants resistant to $L$. coffeella and $H$. vastatrix were identified as clone 760 (H14950-7 C760 EP473), clone 1064 (H148446 C1064 EP 473), clone 1059 (H13685-1-25 C1059 EP473 and clone 1215 (H14954-43 C1215 EP473). The cultivar Obatã IAC 1669-20 was used as susceptible pattern in two control treatments, with and without pest chemical control. Clones were evaluated under field conditions, spaced $3 \mathrm{~m}$

\footnotetext{
${ }^{1}$ Instituto Agronômico (IAC), CP 28, 13.020-902, Campinas, SP, Brazil. *E-mail: oliveiro@iac.sp.gov.br
} 
between rows and $1 \mathrm{~m}$ between plants, using randomized block design with five replications, and experimental plots of five plants. Chemical control was carried out using Insecticide Thiamethoxam at dosage of $8 \mathrm{~kg} \mathrm{ha}^{-1}$, twice a year (November and February), starting from November, 2009.

Several traits related to growth, fertility and plant health were evaluated according to the following criteria:

Yield. It was measured in $\mathrm{kg}$ of ripe coffee, and evaluated from 2009 to 2013 in individual plants. 2011 yield was not considered in the analysis due to very low values.

Empty fruit locules. It corresponded to the percentage of fruits with at least one empty locule, evaluated in 2009, 2012 and 2013, from the counting of floating fruit in water.

Self-compatibility. It corresponded to the fruit set in artificial selfing, carried out in 2008 and 2012. Five branches per plot, with variable number of buds, were covered with a paper bag three days before anthesis, and uncovered after fifteen days. The fruit set was measured as the division between the number of normal fruit and the number of flower buds of each branch.

Plant size. It corresponded to the qualitative character - dwarf or normal size - determined by the presence or absence of the allele caturra $(\mathrm{Ct})$, responsible for reduction of internode length of orthotropic stems and of plagiotropic branches.

Height. It corresponded to the length in meters taken from the stem base to the apex of the plants. Coffee trees were also classified in relation to height according to the following classification: - very low, low, medium, high and very high - established in the minimum descriptors list for protection of coffee cultivars, published by the Ministério da Agricultura, Pecuária e Abastecimento (Ministry of Agriculture, Livestock and Supply) (MAPA 2010).

Canopy diameter. It corresponded to the length in meters, taken at $50 \mathrm{~cm}$ from the stem base of the plants.

Fruit ripening. It corresponded to the individual plants evaluated before harvest, from 2009 to 2013, through visual analyses of the amount of fruit at different ripening stages: green, ripe, over-ripe and dried. Coffee trees were scored on a 1-5 point scale, where $1=$ plants with early maturation; $3=$ plants with medium maturation and $5=$ plants with late maturation, considering the predominant ripening pattern of fruit.

Shape of beans. It corresponded to the percentage of flat, peaberry or elephant beans determined for each plant in samples of 100 beans of green coffee.
Mass of 100 beans. It corresponded to the mass in grams of 100 flat beans with $11 \%$ moisture, in 2012 and 2013.

Beans size. It corresponded to the screening of flat beans on a set of sieves with holes ranging from 12/64 to 22/64 inches in diameter (Krug 1940). The mean size is calculated by the weighted mean, multiplying the number of sieve by the respective mass of beans retained therein, adding up the products and dividing the sum by the total mass of beans.

Resistance to coffee leaf miner. It corresponded to the resistance evaluated by tree different methods. The incidence of damage caused by insects was monthly monitored between January 2012 and November 2013, by counting the number of lesions per branch of each plant. Additionally, in October 2012, coffee plants were scored on a 1-5 point scale, where $1=$ plants free of infestation and $5=$ plants highly infested. In order to carry out the analysis of resistance in laboratory, plants were individually evaluated by the method of leaf discs kept in humid chambers after infestation of detached leaves in insect rearing cages. Reaction type was scored on a 1-4 point scale (Ramiro et al. 2004), where $1=$ resistant, with punctual lesions; $2=$ moderately resistant plants, with little filiform lesions; $3=$ moderately susceptible, with large and irregular filiform lesions, and $4=$ susceptible with large and rounded lesions.

Resistance to coffee leaf rust. It corresponded to the resistance evaluated under field conditions, in 2009 and 2013. The reaction type was evaluated at the middle third of coffee plants, according to a 1-5 point scale, adapted from Conceição et al. (2005), where 1=immune, without visible lesions; $2=$ resistant, with little chlorotic lesions, and without spores; $3=$ moderately resistant, with medium to large chlorotic pustules, and low level of sporulation; $4=$ moderately susceptible, pustules with medium level of sporulation, and $5=$ susceptible, pustules with high level of sporulation, without chlorosis. Coffee plants were also evaluated in 2013 regarding lesions density, according to a 1-10 point scale (Eskes and Toma-Braghini 1981), where $1=$ occurrence of few lesions in the lower third branches, and $10=$ lesions in almost all branches, from the base to the apex of the plant.

\section{RESULTS AND DISCUSSION}

The mean yield of four $C$. arabica clones was not statistically different from the experimental controls. However, yield of clone 1059 was $21 \%$ higher than the mean of 'Obatã IAC 1669-20', with and without chemical control (Table 1).

Percentage empty fruit locules, measured in three 
AP Mendonça et al.

Table 1. Mean yield of ripe coffee, percentage of empty fruit locules (EF) and percentage of fruit set in artificial selfing (FS) of Coffea arabica clones

\begin{tabular}{lcccc}
\hline Treatments & \multicolumn{2}{c}{$\begin{array}{c}\text { Mean yield }^{\mathbf{a}} \\
\left(\mathrm{kg} \mathrm{plant}^{-1} \text { year }^{-1}\right)\left(\text { bags ha }^{-1}\right)\end{array}$} & $\begin{array}{c}\mathbf{E F}^{\mathbf{b}} \\
(\%)\end{array}$ & $\begin{array}{c}\mathbf{F S}^{\mathbf{c}} \\
(\%)\end{array}$ \\
\hline Clone 760 & $2.18 \mathrm{ab}$ & 22 & $21.1 \mathrm{a}$ & $41.8 \mathrm{~b}$ \\
Clone 1059 & $2.71 \mathrm{a}$ & 28 & $15.7 \mathrm{a}$ & $52.9 \mathrm{~b}$ \\
Clone 1064 & $1.98 \mathrm{ab}$ & 20 & $20.6 \mathrm{a}$ & $47.1 \mathrm{~b}$ \\
Clone 1215 & $1.67 \mathrm{~b}$ & 17 & $16.6 \mathrm{a}$ & $47.9 \mathrm{~b}$ \\
Obatã NPC & $2.20 \mathrm{ab}$ & 22 & $20.3 \mathrm{a}$ & $67.4 \mathrm{a}$ \\
Obatã PC & $2.07 \mathrm{ab}$ & 21 & $17.8 \mathrm{a}$ & $67.8 \mathrm{a}$ \\
\hline CV $(\%)$ & 48.12 & & 40.08 & 16.83 \\
\hline
\end{tabular}

Means of treatments followed by the same letter do not significantly differ $(P<0.05)$ according to the Newman Keuls;

${ }^{a}$ Means of four harvests of progeny trial PT 540;

beans of three evaluations; ' Means of two evaluations;

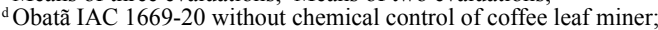

'Obatã IAC 1669-20 with chemical control of coffee leaf miner.

harvests, was high in clones and in controls, ranging from $15.7 \%$ to $21.1 \%$, without statistical differences between treatments. Mean values of fruit set in controlled selfing were higher in experimental controls. Percentage of fruits with flat beans in relation to the number of flowers pollinated was close to $67 \%$ in 'Obatã IAC 1669-20', with or without chemical control, whereas the means observed in clones ranged between 42 and 53\% (Table 1).

All clones showed dwarf size, with short internodes both in orthotropic and in plagiotropic branches, and medium height, according to the Brazilian list of minimum descriptors for protection of coffee cultivars. Coffee plants of clone 1059 had the highest height, about $20 \mathrm{~cm}$ taller than plants of 'Obatã IAC 1669-20', whereas plants of clone 1215 showed the lowest height and the smallest canopy diameter, being considered the germplasm with the most compact architecture (Table 2).

Fruit ripening of clones was evaluated by the calculation of the means of four harvests, from data obtained from individual plants, as well as from the percentage of early, medium and late maturation plants, in each treatment. It revealed that, on average, the four clones achieve maturation earlier than the controls. 'Obatã IAC 1669-20', with or without chemical control, showed mean values of ripening around 4 , being $89 \%$ of plants classified as medium or late maturation. Considering all clones, the percentage of plants with early maturation ranged from $31 \%$ to $45 \%$ (Table 2 ).

The highest means of flat beans was observed in controls, while clones presented 20\% lower mean values (Table 3 ). Percentage of peaberry beans in clones was about twice as higher than that observed in controls. Incidence of elephant beans, a defect in commercial classification, was higher in clones 1215, 760 and 1064, but no statistical differences were observed between controls and clone 1059 .

Mass of 100 flat beans ranged from 14.1g (clone 1059) to $15.7 \mathrm{~g}$ (clone 760 ), but no differences were observed between treatments, and there was no range in medium size of flat beans (Table 3).

Regarding incidence of $L$. coffeella in C. arabica clones and in controls, the highest number of lesions per leaf on labeled branches was observed in 'Obatã IAC 1669-20' without chemical control. Intermediate values were observed in the control with chemical control, and in clone 1059, in periods of high incidence of insects in field (Figure 1).

Evaluation carried out both under field conditions and in laboratory pointed to high resistance level of clones to $L$. coffeella (Table 4). Chemical control in 'Obatã IAC 166920 ' was effective, once the means of infestation was lower than in the control without insecticide.

'Obatã IAC 1669-20' was classified as resistant to coffee leaf rust according to evaluation under field conditions in

Table 2. Plant size, height, canopy diameter, mean fruit ripening and percentage of coffee plants of Coffea arabica clones, classified as early, medium or late

\begin{tabular}{|c|c|c|c|c|c|c|c|c|}
\hline \multirow{2}{*}{ Treatments } & \multirow{2}{*}{ Plant Size $^{a}$} & \multirow{2}{*}{ Height $^{\mathrm{b}}$} & \multirow{2}{*}{ Height of coffee plants ${ }^{\mathrm{c}}$} & \multirow{2}{*}{ Canopy diameter } & \multicolumn{4}{|c|}{ Fruit ripening $^{\mathrm{d}}$} \\
\hline & & & & & Mean & Early & Medium & Late \\
\hline & & & \multicolumn{2}{|c|}{------------- m ------------ } & Points & \multicolumn{3}{|c|}{----------0\%---------- } \\
\hline Clone 760 & $\mathrm{D}$ & M & $2.09 \mathrm{abc}$ & $2.10 \mathrm{a}$ & $2.51 \mathrm{~b}$ & 42 & 40 & 18 \\
\hline Clone 1059 & $\mathrm{D}$ & M & $2.20 \mathrm{a}$ & $2.14 \mathrm{a}$ & $3.07 \mathrm{~b}$ & 31 & 33 & 36 \\
\hline Clone 1064 & $\mathrm{D}$ & M & $2.15 \mathrm{ab}$ & $2.12 \mathrm{a}$ & $2.55 \mathrm{~b}$ & 45 & 33 & 22 \\
\hline Clone 1215 & $\mathrm{D}$ & M & $1.95 \mathrm{c}$ & $1.85 \mathrm{~b}$ & $2.76 \mathrm{~b}$ & 38 & 33 & 29 \\
\hline $\mathrm{CV}(\%)$ & & & 12.18 & 9.53 & 7.05 & & & \\
\hline
\end{tabular}

Means of treatments followed by the same letter do not significantly differ $(P<0.05)$ according to the Newman Keuls;

a Presence of allele $C t$ in dwarf (D) plants;

${ }^{\mathrm{b}} \mathrm{M}=$ medium, according to the table of minimum descriptors for coffee cultivars protection;

${ }^{\mathrm{c}}$ Evaluations carried out in 2013;

${ }^{\mathrm{d}}$ Means of five harvests and percentage of plants distributed in fruit ripening classes;

e Obatã IAC 1669-20 without chemical control of coffee leaf miner;

${ }^{\mathrm{f}}$ Obatã IAC 1669-20 with chemical control of coffee leaf miner. 
2009. Intermediate levels of resistance to the fungus were observed in clones 1059, 760 and 1064. In 2013, Obatã IAC 1669-20 was classified as susceptible to $H$. vastatrix, due to a large number of pustules with high intensity of sporulation on leaves, scored close to 5 on the scale used. In that year, clones showed high values regarding the type of reaction to coffee leaf rust. However, density of lesions in leaves of clones 1059, 760 and 1064 was lower than that observed

Table 3. Mean percentage of flat (F), peaberry (P) and elephant (E) beans, mass of 100 beans (MB) and beans size (BS) of Coffea arabica clones

\begin{tabular}{|c|c|c|c|c|c|}
\hline \multirow{2}{*}{ Treatments } & \multicolumn{3}{|c|}{ Shape of beans a } & \multirow{2}{*}{$\mathbf{M B}^{\mathbf{a}}$} & \multirow{2}{*}{$\mathbf{B S}^{\mathbf{a}}$} \\
\hline & $\mathbf{F}$ & $\mathbf{P}$ & $\mathbf{E}$ & & \\
\hline & \multicolumn{3}{|c|}{ 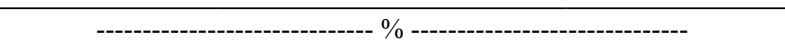 } & $\mathrm{g}$ & \\
\hline Clone 760 & $54.1 \mathrm{~d}$ & $37.3 \mathrm{a}$ & $8.6 \mathrm{a}$ & $15.7 \mathrm{a}$ & $17-18$ \\
\hline Clone 1064 & $56.7 \mathrm{~d}$ & $34.6 \mathrm{a}$ & $8.6 \mathrm{a}$ & $14.3 \mathrm{a}$ & 17 \\
\hline Clone 1215 & $62.0 \mathrm{c}$ & $29.9 \mathrm{~b}$ & $8.1 \mathrm{a}$ & $14.8 \mathrm{a}$ & 17 \\
\hline $\mathrm{CV}(\%)$ & 9.07 & 21.76 & 44.06 & & \\
\hline
\end{tabular}

Means of treatments followed by the same letter do not significantly differ $(P=0.05)$ according to the Newman Keuls mean separation test;

${ }^{\text {a }}$ Means of two evaluations (2012 e 2013);

${ }^{\mathrm{b}}$ Obatã IAC 1669-20 without chemical control of coffee leaf miner;

${ }^{c}$ Obatã IAC 1669-20 with chemical control of coffee leaf miner.

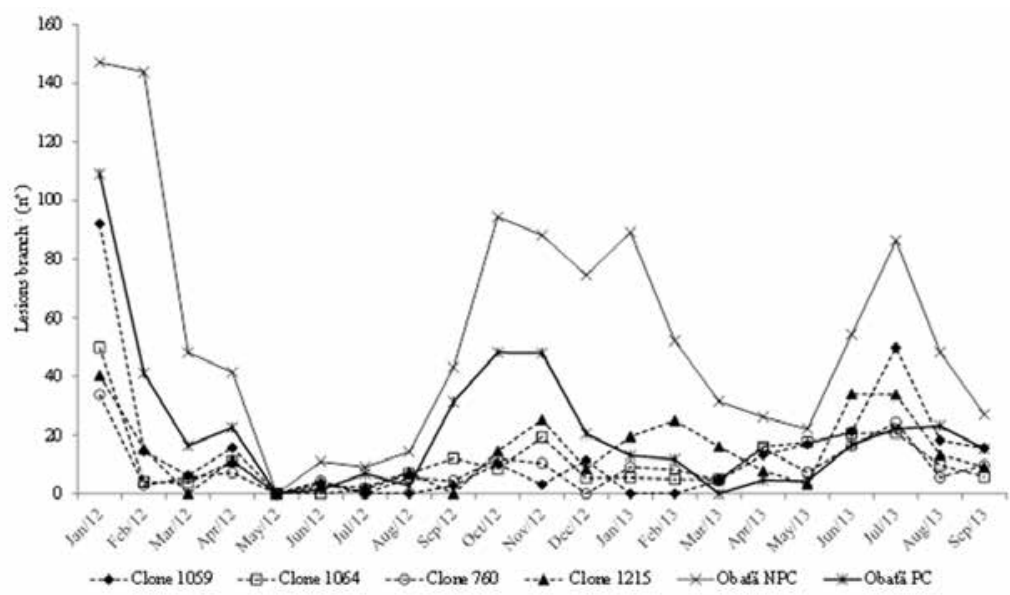

Figure 1. Population fluctuation of Leucoptera coffeella in Coffea arabica clones evaluated by the number of lesions in labeled branches from January 2012 to September 2013.

Table 4. Resistance of mother plants of Coffea arabica and their clones to coffee leaf miner and to coffee leaf rust, under field and laboratory conditions

\begin{tabular}{|c|c|c|c|c|c|}
\hline \multirow{2}{*}{ Treatments } & \multicolumn{2}{|c|}{ Coffee leaf miner $^{\mathrm{a}}$} & \multicolumn{3}{|c|}{ Coffee leaf rust (Field) ${ }^{b}$} \\
\hline & Field & Laboratory & RT $_{2009}$ & $\mathbf{R T}_{2013}$ & LD $_{2013}$ \\
\hline & \multicolumn{2}{|c|}{--------------points---------------- } & \multicolumn{3}{|c|}{----------------points---------------- } \\
\hline Clone 760 & $1.4 \mathrm{c}$ & $1.8 \mathrm{c}$ & $2.4 \mathrm{~b}$ & $4.0 \mathrm{c}$ & $2.5 \mathrm{c}$ \\
\hline Clone 1059 & $1.2 \mathrm{c}$ & $1.7 \mathrm{c}$ & $2.6 \mathrm{~b}$ & $4.4 \mathrm{~b}$ & $2.9 \mathrm{c}$ \\
\hline Clone 1064 & $1.3 \mathrm{c}$ & $1.6 \mathrm{c}$ & $2.3 \mathrm{~b}$ & $4.4 \mathrm{~b}$ & $3.0 \mathrm{c}$ \\
\hline Clone 1215 & $1.4 \mathrm{c}$ & $2.3 \mathrm{bc}$ & $3.0 \mathrm{a}$ & $4.9 \mathrm{a}$ & $5.0 \mathrm{a}$ \\
\hline $\mathrm{CV}(\%)$ & 30.2 & 40.2 & 29.3 & 15.1 & 30.9 \\
\hline
\end{tabular}

Means of treatments followed by the same letter do not significantly differ $(P=0.05)$ according to the Newman Keuls mean separation test;

${ }^{a}$ Coffee plants resistance level to coffee leaf miner evaluated under field and laboratory conditions by lesion type, according to a $1-5$ points scale;

${ }^{b}$ Coffee plants resistance level to coffee leaf rust evaluated under field conditions by reaction type (RT), according to a 1-5 points scale, and by the lesions density (LD), according to a $1-10$ points scale;

${ }^{c}$ Obatã IAC 1669-20 without chemical control of coffee leaf miner;

d Obatã IAC 1669-20 with chemical control of coffee leaf miner. 
in controls and in 1215, which presented the highest mean.

Since this is a non-irrigated field trial, analysis of water
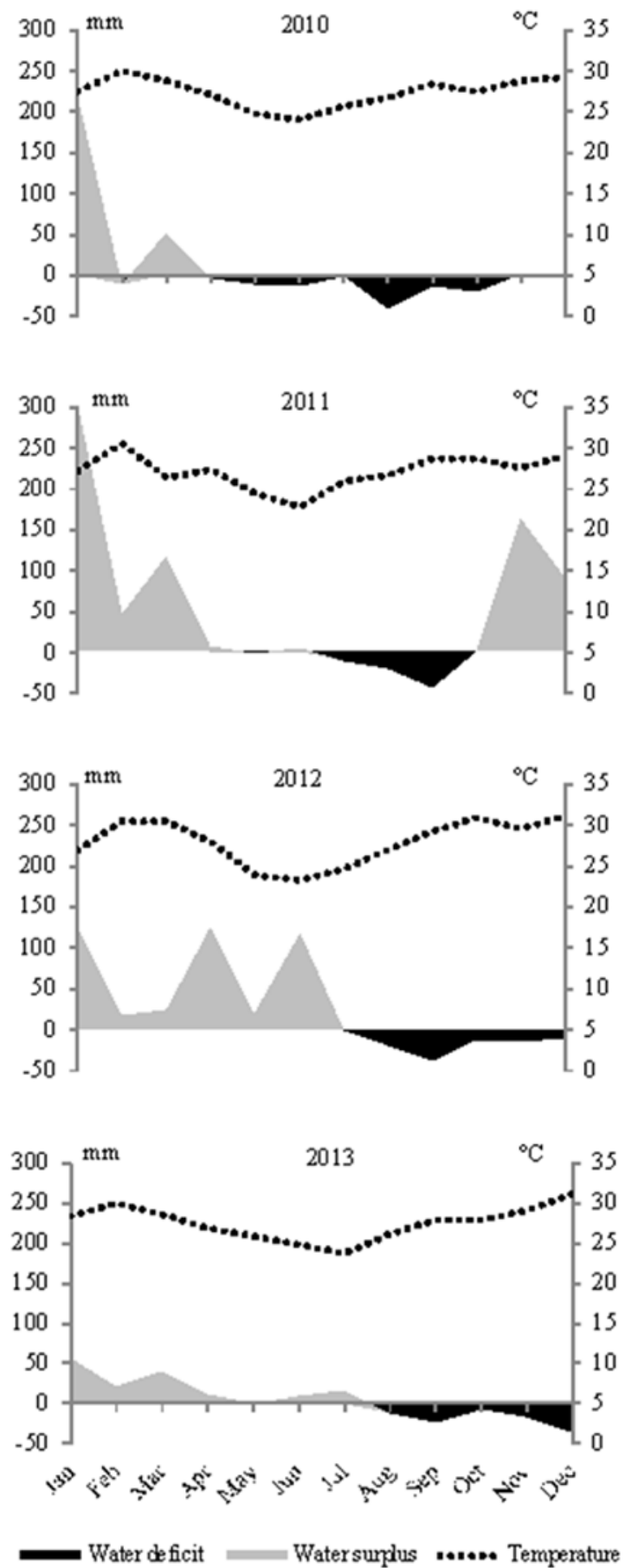

Figure 2. Analysis of the water balance in production cycles of Coffea arabica clones from 2010 to 2013. balance in the two production cycles from 2010 to 2013 must be considered. Therefore, the drought and higher temperatures observed during the period of data collection (Figure 2) also reflected on the lower yield of clones and controls, which demand more water (Carvalho et al. 2008) than coffee cultivars that had been planted before. High temperatures in periods coincident with flowering, and water deficiency during the expansion and beans filling phases may also explain the higher percentages of empty fruit locules both in clones and in the commercial cultivar 'Obatã IAC 1669-20' (Figure 2).

Climatic variables also influence on the autoincompatibility of flowering, which can vary among species. The rate of fruit set in commercial Arabica cultivars, such as Catuaí Vermelho, ranges between $40 \%$ and $60 \%$ (Carvalho et al. 1983). However, coffee plants generated by interspecific hybridization, such as the evaluated clones, may present levels of sterility (Vacarelli et al. 2003) or incompatibility (Carvalho et al. 1983), resulting in reduction of fruit production after pollination.

The highest rates of fruit set in controlled selfing were observed in coffee plants of 'Obatã IAC 1669-20'. However, the rates of fruit set of clones were close to those presented by commercial cultivars, which are satisfactory for a new cultivar.

In spite of small variations in the height and canopy diameter, the four clones exhibited dwarf size, suggesting that their mother plants have at least one $C t$ allele, once the characteristic is controlled by expression of a dominant gene named caturra (Carvalho et al. 1984).

Among the measured technological characteristics of beans, only the shape varied between clones and controls. All treatments showed 91.4\% (clone 760 and clone 1064) to $96.3 \%$ ('Obatã IAC 1669-20' without chemical control) of flat and peaberry beans.

Clone 1059 was not different from controls on percentage of elephant beans; however, the other clones showed slightly higher percentages. As the shape of beans is a characteristic that is highly influenced by environment conditions (Antunes Filho 1953), percentage of elephant beans should be lower in rainy years and in mild temperatures, since under these conditions the percentage of this defect in commercial cultivars is close to zero.

During all the period of experimental evaluation, incidence of $L$. coffeella was higher in leaves of controls, especially in plants without chemical control. Clones were always less infested. The insect fluctuation curve (Figure 1) follows the typical distribution of the pest with two annual 
peaks (Souza et al. 1998). The high number of lesions in labeled branch, which is an indicator of the pest incidence, is mainly due to secondary branching of the primary branches initially labeled, and also due to the presence of remaining lesions, as result of greater leaf retention. This is a characteristc of coffee plants with some level of resistance to coffee leaf rust (Conceição et al. 2005). Severity of damage, evaluated under field and laboratory conditions, demonstrated that the four clones maintained the insect resistance of their mother plants throughout the period of evaluation.

The same was not true in relation to coffee leaf rust. The type of reaction of coffee plants evaluated in 2013 was greater than that observed in 2009. This suggests the emergence

\section{REFERENCES}

Antunes Filho H (1953) Sementes 'moca' e 'concha' no café Mundo Novo. Boletim da Superintendência dos Serviços do Café 28: 8-16.

Braghini MT, Fazuoli LC and Mantovani ES (2011) Levantamento de raças de Hemileia vastatrix Berk. and Br. em cafeeiros derivados de Híbrido de Timor. In Proceedings of VII Simpósio de Pesquisa dos Cafés do Brasil. Embrapa Café, Brasília. Available at $<$ http://www. sapc.embrapa.br/arquivos/consorcio/spcb_anais/simposio7/259.pdf >. Accessed on April 20, 2015.

Bertrand B, Alpizar E, Lara L, Santacreo R, Hidalgo M, Quijano JM, Montagnon C, Georget F, Etienne H (2011) Performance of Coffea arabica $\mathrm{F}_{1}$ hybrids in agroforestry and full-sun cropping systems in comparison with American pure line cultivars. Euphytica 181: 147-158.

Carvalho A, Costa WM and Fazuoli LC (1983) Auto-incompatibilidade, produtividade, ocorrência de sementes do tipo moca e mudas anormais no café Icatu. Bragantia 42: 157-169.

Carvalho A, Medina-Filho HP, Fazuoli LC and Costa WM (1984) Genética de Coffea XXVI. Hereditariedade do porte reduzido do cultivar Caturra. Bragantia 43: 443-458.

Carvalho CHS, Fazuoli LC, Carvalho GR, Guerreiro-Filho O, Pereira AA, Almeida SR, Matiello JB, Bartholo GF, Sera T, Moura WM, Mendes ANG, Resende JC, Fonseca AFA, Ferrão MAG, Ferrão RG, Nacif AP, Silvarolla MP, Braghini MT and Sera GH (2008) Cultivares de café arábica de porte baixo. In Carvalho CSH (ed) Cultivares de café: origem, características e recomendações. Embrapa Café, Brasília, p. 157-224.

Conceição AS, Fazuoli LC and Braghini MT (2005) Avaliação e seleção de progênies $\mathrm{F}_{3}$ de cafeeiros de porte baixo com o gene $\mathrm{SH}_{3}$ de resistência a Hemileia vastatrix Berk. et Br. Bragantia 64: 547-559.

Del Grossi L, Sera T, Sera GH, Fonseca ICB, Ito DS, Shigueoka LH, Andreazi E and Carvalho FG (2013) Rust resistance in Arabic coffee cultivars in northern Paraná. Brazilian Archives of Biology and Technology 56: 27-33. of new races of the fungus, according to Braghini et al. (2011) and Del Grossi et al. (2013), which are pathogenic both to clones, and to 'Obatã IAC 1669-20'. Density of lesions, also evaluated in 2013, confirms susceptibility of the evaluated genotypes.

In spite of their rust susceptibility, clones 1059, 1064 and 760 showed lower severity disease and density of rust lesions, suggesting the occurrence of incomplete resistance, probably due to the polygenic inheritance of trait. Clone 1059 showed lower percentage of flat beans and higher percentage of peaberry, when compared with controls. However, in view of yield and leaf miner resistance, it is potentially feasible the adoption this genotype as a new clonal cultivar.

Eskes AB and Toma-Braghini MT (1981) Assessment methods for resistance to coffee leaf rust (Hemileia vastatrix Berk. and Br.). FAO Plant Protect Bulettin 29: 56-66.

Fazuoli LC, Carvalho CHS, Carvalho GR, Guerreiro-Filho O, Pereira AA, Bartholo GF, Moura WM, Silvarolla MP and Braghini MT (2008) Cultivares de café arábica de porte alto. In Carvalho CSH (ed) Cultivares de café: origem, características e recomendações. Embrapa Café, Brasília, p. 227-254.

Guerreiro-Filho O (2006) Coffee leaf miner resistance. Brasilian Journal of Plant Physiology 18: 109-117.

Guerreiro-Filho O, Silvarolla MB and Eskes AB (1999) Expression and mode of inheritance of resistance in coffee to leaf miner Perileucoptera coffeella. Euphytica 105: 7-15.

Krug CA(1940) O cálculo da peneira média na seleção do cafeeiro. Revista do Instituto do Café 15: 123-127.

MAPA - Ministério da Agricultura, Pecuária e Abastecimento (2010) Serviço Nacional de Proteção de Cultivares: Instruções para execução dos ensaios de distinguibilidade, homogeneidade e estabilidade de cultivares de café (Coffea spp). Available at $<\mathrm{http}$ :// www.agricultura.gov.br/arq_editor/file/vegetal/RegistroAutorizacoes/ Formularios $\% 20$ Prote $\% \mathrm{C} 3 \% \mathrm{~A} 7 \% \mathrm{C} 3 \% \mathrm{~A} 30 \% 20$ Cultivares/CAFE_ US.doc $>$. Accessed on April 7, 2015.

Medina-Filho HP, Bordignon R, Guerreiro-Filho O, Maluf MP and Fazuoli LC (2007) Breeding of arabica coffee at IAC, Brazil: Objectives, problems, and prospects. Acta Horticulturae 745: 393-408.

Ramiro DA, Guerreiro-Filho O, Queiroz-Voltan RB and Matthiesen SC (2004) Caracterização anatômica de folhas de cafeeiros resistentes e suscetíveis ao bicho-mineiro. Bragantia 63: 363-372.

Souza JC, Reis PR and Rigitano RL (1998) O bicho-mineiro-do-cafeeiro: biologia, danos e manejo integrado. Epamig, Belo Horizonte, 48p.

Vacarelli VN, Medina-Filho HP and Fazuoli LC (2003) Avaliação de frutos chochos e de sementes do tipo moca no rendimento de híbridos arabustas tetraploides (Coffea arabica x Coffea canephora). Bioscience Journal 19: 155-165. 